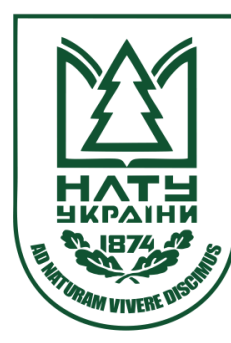

Науковий вісник НлтУ України

Scientific Bulletin of UNFU

ISSN 1994-7836 (print)

http://nv.nltu.edu.ua

https://doi.org/10.15421/40280410

Article received 17.03.2018 p.

Article accepted 26.04.2018 p.

2 Correspondence author

удк 378.14:338.48(477.83)

G. Ya. Dutka
dutkaanna@ukr.net

Львівський інститут економіки і туризму, м. Львів, Украйна

\title{
КОНКУРЕНТОСПРОМОЖНІСТЬ ЗАКЛАДІВ ВИЩОЇ ОСВІТИ ЛЬВІВСЬКОЇ ОБЛАСТІ У ПІДГОТОВЦІ МАЙБУТНІХ ФАХІВЦІВ ТУРИСТИЧНОГО ТА ГОТЕЛЬНО-РЕСТОРАННОГО БІЗНЕСУ
}

\begin{abstract}
Досліджено тенденції та перспективи розвитку туристичного та готельно-ресторанного бізнесу України. Порівняльний аналіз наукових праць вітчизняних і зарубіжних науковців показав, що однією з умов ефективного розвитку туристичної сфери та готельно-ресторанного бізнесу $є$ наявність висококваліфікованих кадрів, які здатні приймати ефективні управлінські рішення, забезпечуючи конкурентоспроможність як окремих підприємств, так і галузі загалом. Посилення конкуренції у сфері освітньої діяльності вимагає від закладів вищої освіти постійно вдосконалювати свою діяльність за всіма іії напрямами, покращувати якість викладання, що мобілізує заклад у ринкових умовах. Проаналізовано сучасний стан закладів вищої освіти України у сфері обслуговування; визначено рейтингову позицію закладів вищої освіти Львівщини. Досліджено концепції і механізми підвищення конкурентоспроможності закладів вищої освіти в сучасних умовах. Виявлено конкурентні позиції та рівень використання освітнього потенціалу закладами вищої освіти Львівської області підготовки фахівців сфери обслуговування, зокрема, за спеціальностями 241 "Готельно-ресторанна справа" та 242 "Туризм" за даними вступної кампанії 2017 р. Запропоновано інноваційні методи та форми, які доцільно впроваджувати в освітній діяльності закладів вищої освіти задля підвищення їхньої конкурентоспроможності, покращення якості освітніх послуг та підготовки кваліфікованих фахівців.
\end{abstract}

Ключові слова: заклад вищої освіти; сфера послуг; туризм; готельно-ресторанна справа; вартість навчання; ліцензований обсяг прийому; загальний конкурс; інноваційні методи навчання.

Вступ. У сучасних умовах господарювання у сфері вищої освіти триває посилення конкуренції щодо надання освітніх послуг. Конкурентні переваги мають ті навчальні заклади та спеціальності, які забезпечують вищу якість підготовки фахівців, коли отримана освіта гарантуватиме майбутнім фахівцям реалізацію власних здібностей, отримання сучасних знань, умінь і навичок, достатній рівень оплати праці, конкурентоспроможність як фахівців на ринку праці. Оцінювання конкурентоспроможності є одним із важливих аспектів управління підприємствами і підгрунтям для розроблення заходів щодо усунення недоліків у роботі та розвитку підприємства у майбутньому (Savitska \& Savitska, 2013). Динамічний розвиток індустрії туризму потребує підготовки висококваліфікованих кадрів галузі. Роль сфери послуг, зокрема, туризму та готельно-ресторанного бізнесу, невпинно зростає як у світі, так і на вітчизняному ринку. Так, згідно зі статистичними даними ВТО, в перші чотири місяці 2017 р. туризм досяг найкращих результатів за 12 років, туристичні потоки впродовж I півріччя 2017 р. зазнали шестивідсоткового зростання порівняно 3 аналогічним періодом попереднього року, що значно перевищує тенденцію останніх років, зробивши цей період найкращим з 2010 р. (www.media.unwto.org/ru/press-release/2017), а наприкін- ці 2017 р. міжнародні потоки туристів зросли на 7 \% до загальної кількості 1,322 млн осіб.

Очікують, що цей сильний імпульс продовжиться у 2018 р. у розмірі 4-5\%. Як наведено у звітах ВТО (www.e-unwto.org/doi), туризм став одним з найбільших та найшвидше зростаючим сектором економіки у світі. Для туризму характерне безперервне зростання, незважаючи на тимчасові потрясіння та кризи. Міжнародні туристичні потоки зросли від 25 млн по всьому світі у 1950 р. до 278 мільйонів у 1980 р., у 2000 р. - 674 млн, а в 2016 р. - 1235 млн осіб. Аналогічно, міжнародні туристські надходження, отримані від подорожей по всьому світу, зросли від 2 млрд дол. США у 1950 р. до 104 млрд дол. США у 1980 р., 495 млрд дол. США у 2000 р. та 1220 млрд дол. США у 2016 р. Окрім цього, туризм є основною категорією міжнародної торгівлі послугами. На сьогодні міжнародний туризм становить 7 \% світового експорту товарів і послуг.

Туризм зростав швидше, ніж світова торгівля впродовж 2012-2016 pp. Тенденції до зростання характерні і для вітчизняного туристичного ринку. Так, за даними Державної служби статистики України (www.ukrstat.gov.ua), мережа суб'єктів туристичної діяльності України - юридичних осіб та фізичних осібпідприємців - у 2016 р. становила 3506 одиниць, що на

\section{Інформація про авторів:}

Дутка Ганна Яківна, д-р пед. наук, професор, кафедра природничо-математичних дисциплін, проректор з навчальнометодичної та виховної роботи. Email: dutkaanna@ukr.net

Цитування за ДСтУ: Дутка Г. Я. Конкурентоспроможність закладів вищої освіти Львівської області у підготовці майбутніх фахівців туристичного та готельно-ресторанного бізнесу. Науковий вісник НлтУ України. Серія Економічна. 2018, т. 28, № 4. С. 56-62

Citation APA: Dutka, Ya. G. (2018). Competitiveness of Higher Education Institutions of Lviv Region in the Preparation of Future Factors of the Tourist and Hotel Restaurant Business. Scientific Bulletin of UNFU, 28(4), 56-62. https://doi.org/10.15421/40280410 
324 одиниці більше, ніж у 2015 р. Кількість туристів громадян України, обслугованих суб'єктами туристичної діяльності впродовж 2016 р., становила понад 2,5 млн осіб, іноземних туристів - 35 тис. осіб (що відповідно на 25 і 133,3\% більше, ніж у 2015 р.). Висхідні тренди можемо спостерігати і в сфері готельно-ресторанного бізнесу. Так, у 2016 р. в Україні надання місць для проживання здійснювали 4256 колективних засобів розміщування (юридичні особи та фізичні особи-підприємці) із кількістю місць - 376 тис. (у 2015 р. відповідно 4341 та 404 тис.). Кількість розміщених у них становила 6544,8 тис. осіб, що на 764,9 тис. осіб (13\%) більше, ніж у 2015 р. Більшість відвідувачів (77\%) надавали перевагу готелям та аналогічним засобам розміщування. Серед розміщених осіб $13 \%$ становили іноземці.

Львівська область $є$ одним 3 найпривабливіших i найпопулярніших туристично-рекреаційних регіонів України. На підтвердження розвитку туристичної та готельно-ресторанної сфери у цьому регіоні, наведемо такі дані Головного управління статистики у Львівській обл. (www.lv.ukrstat.gov.ua):

1) протягом 2016 р. в області діяли 272 суб'єкти туристичної діяльності. Їх послугами скористалися 181,8 тис. осіб (у 2015 р. - 112,5 тис. осіб), з яких 95,4 \% - громадяни України. Суб'єкти туристичної діяльності у 2016 р. обслужили 17,6 тис. екскурсантів, що на 17,6 \% більше, як у попередньому році. 32014 р. у Львівській обл. спостерігається динаміка зростання кількості туристів та екскурсантів, обслужених суб'єктами туристичної діяльності (рис. 1) та обсягів реалізованих послуг туристичних агентств і туристичних операторів (рис. 2).

2) у 2016 р. на Львівщині діяли 287 готельних закладів та 56 спеціалізованих (санаторно-курортних та відпочинкових) засобів розміщування.

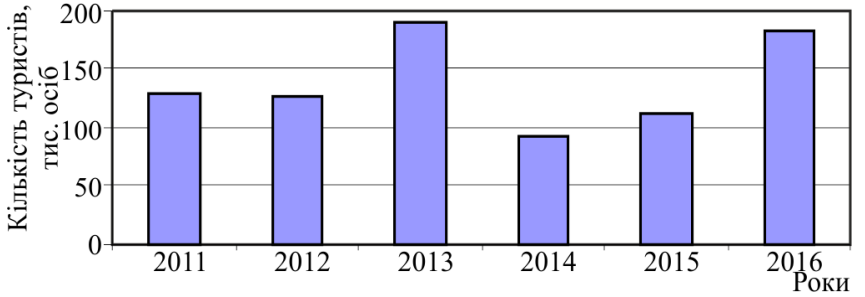

Рис. 1. Динаміка кількості туристів та екскурсантів, обслужених суб'єктами туристичної діяльності у Львівській області (www.lv.ukrstat.gov.ua)

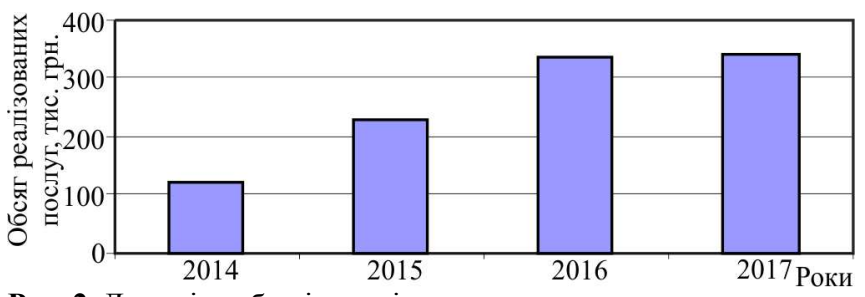

Рис. 2. Динаміка обсягів реалізованих послуг туристичних агентств, туристичних операторів у Львівській області (www.lv.ukrstat.gov.ua)

Упродовж року їх послугами скористалися 861,3 тис. осіб, зокрема, 106,8 тис. іноземців. Упродовж року у готелях та аналогічних засобах розміщення зупинялися 749,9 тис. приїжджих. Порівняно з 2015 р. їх кількість збільшилась на 158,6 тис. осіб (на 26,8 \%). Натомість кількість гостей, що оздоровились та відпочили у спеціалізованих закладах, скоротилась на 12,6 тис. осіб (на 10,2\%) і становила 111,4 тис. осіб. Кількість іноземних громадян, які скористалися послугами готельних закладів, порівняно з 2015 р. зросла 46,9\%, спеціалізованих закладів - на 12,9 \% (www.lv.ukrstat.gov.ua). Динаміку кількості готелів та аналогічних закладів розміщування у Львівській обл. зображено на рис. 3, а кількості розміщених у цих закладах - на рис. 4.

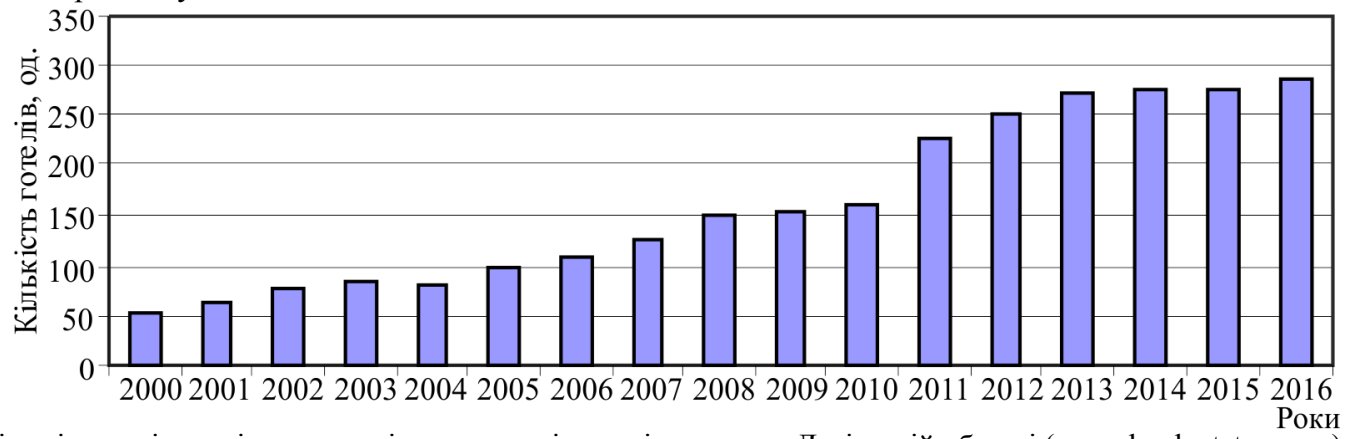

Рис. 3. Динаміка кількості готелів та аналогічних закладів розміщування у Львівській області (www.lv.ukrstat.gov.ua)

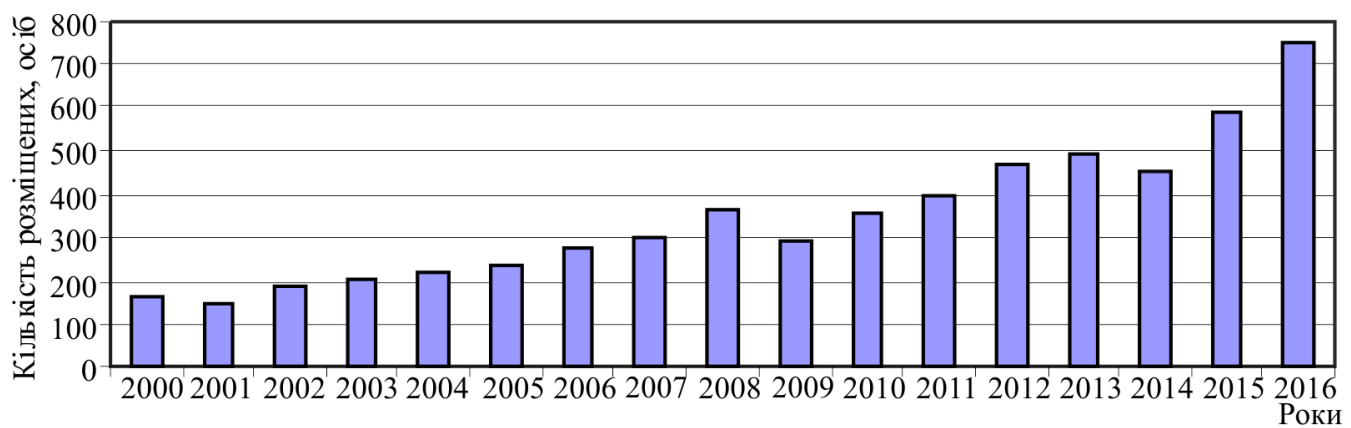

Рис. 4. Динаміка кількості розміщених осіб у готелях та аналогічних закладах розміщування у Львівській області (www.lv.ukrstat.gov.ua)

Як підтверджують статистичні дані, для туризму та готельно-ресторанного бізнесу України (зокрема, для Львівської обл.) характерні позитивні тенденції та великі перспективи розвитку (Grytsyuk \& Hrytsiuk, 2013).
Стрімкий ріст сфери послуг вимагає професійної підготовки фахівців у цій сфері, попит на яких постійно зростає. За даними ВТО, на сферу туризму припадає 10 \% усіх працівників (https://www.e-unwto.org/doi/pdf/). 
На думку О. Бутенко (Butenko \& Strelchenko, 2016), позитивна динаміка розвитку сфери послуг за останні роки у Київській, Львівській, Дніпровській, Харківській областях пов'язана 3 розташуванням певної кількості навчальних закладів, які значно впливають на кількість споживачів та різноманітність видів туризму і ресторанного господарства. Однією з основних умов ефективного розвитку туристичної сфери та готельно-ресторанного бізнесу $є$ наявність висококваліфікованих кадрів, які здатні швидко і правильно реагувати на вплив чинників внутрішнього та зовнішнього середовища, враховувати наявні ризики, приймати ефективні управлінські рішення, забезпечуючи конкурентоспроможність як окремих підприємств, так і галузі загалом. Все це доводить потреба покращення ефективності роботи закладів вищої освіти, які надають освітні послуги у сфері послуг. Підвищення їхньої конкурентоспроможності сприятиме більшому залученню студентів на навчання, а використання інноваційних методів в освітній діяльності дасть змогу підготувати кваліфікованих спеціалістів на туристичному ринку праці.

Аналіз останніх досліджень і публікацій. Питання підготовки фахівців у закладах вищої освіти України у сфері туризму досліджували такі вітчизняні науковці, як: І. Бочан, Л. Безкоровайна, О. Конох, В. Лозовецька, В. Сергійко, В. Шафранський; готельно-ресторанної справи - М. Бабешко, А. Гуцол, І. Ощипок та ін. Багато науковців присвятили свої дослідження вивченню особливостей та потреби використання інноваційних технологій під час підготовки майбутніх фахівців у сфері туризму та готельно-ресторанної справи, а саме: А. Віндюк, О. Кашинська, Н. Маковецька, І. Мартинюк, К. Піцул, К. Трофімук та ін. У більшості наукових праць розглядають питання діяльності закладів вищої освіти у сфері туризму та готельно-ресторанної справи на рівні держави, при цьому недостатньо висвітлено аспекти конкурентоспроможності ЗВО на регіональному рівні, зокрема, у Львівській обл., що потребує додаткового дослідження.

Мета роботи - виявити конкурентні позиції та рівень використання освітнього потенціалу закладами вищої освіти Львівської обл. у сфері обслуговування, зокрема, щодо підготовки майбутніх фахівців за спеціальностями 241 "Готельно-ресторанна справа" та 242 "Туризм" (за даними вступної кампанії 2017 р.), а також запропонувати інноваційні методи та форми, які доцільно впроваджувати в навчальній діяльності закладів вищої освіти задля підвищення їхньої конкурентоспроможності, покращення якості освітніх послуг та підготовки кваліфікованих спеціалістів.

Викладення основного матеріалу дослідження. За останні роки галузеві стандарти вищої освіти (BO) 3 підготовки фахівців 3 туризму та гостинності змінювалися, що ускладнювало професійну підготовку у закладах ВО України. 32002 р. у закладах ВО розпочато підготовку фахівців з гостинності напряму "Туризм". У 2004 р. затверджено галузевий стандарт 3 відповідного напряму, до якого належать спеціальності "Готельне господарство" та "Туризм". У 2006 р. до переліку напряму внесено спеціальність "Готельно-ресторанна справа". У 2007 р. затверджено галузевий стандарт підготовки майбутніх фахівців 3 напряму "Готельно-ресторанна справа" відповідно до освітньо-кваліфікаційного рівня "бакалавр", у 2011 р. - "спеціаліст" і "магістр"
(Babeshko, 2016). У 2016 р. розробляють галузеві стандарти вищої освіти України з галузі знань 24 "Сфера обслуговування" спеціальностей 241 "Готельно-ресторанна справа" та 242 "Туризм". За даними "Довідника BH3" (www.osvita.ua/vnz/guide6) у 2017/2018 н. р. в Україні підготовку студентів з галузі знань 24 "Сфера обслуговування" здійснюють 128 закладів вищої освіти III та IV рівнів акредитації, зокрема, 83 - зі спеціальності 241 "Готельно-ресторанна справа" та 105 - зі спеціальності 242 "Туризм". Загальна кількість закладів вищої освіти в Україні на початок 2017/2018 н. р. становила 661 установу, тобто 19,4 \% 3 цього числа надавали освітні послуги у сфері туризму. Найбільше закладів вищої освіти географічно розміщено у Києві (21 заклад) та таких областях: Запорізькій - 9 закладів, Львівській 7 закладів, Дніпропетровській - 6 закладів, Миколаївській - 6 закладів, Полтавській - 6 закладів. Як бачимо, Львівська обл. є одним з лідерів за кількістю закладів вищої освіти, які здійснюють підготовку студентів галузі знань 24 "Сфера обслуговування", що свідчить про перспективи розвитку цього напряму у західному регіоні України.

Для виявлення конкурентних позицій та рівня використання освітнього потенціалу закладів вищої освіти Львівської обл. у сфері обслуговування, подамо їхню характеристику за такими показниками (за даними вступної кампанії 2017 р. для першого курсу освітніх ступенів (ОС) "бакалавр" і "магістр"), як: вартість одного року навчання, кількість поданих заяв абітурієнтами, кількість зарахованих абітурієнтів на навчання, ліцензований обсяг прийому, загальний конкурс (табл. 1).

Відповідно до даних табл. 1, тільки Львівський інститут економіки і туризму є спеціалізованим, профільним закладом вищої освіти, який здійснює прийом на навчання студентів за двома спеціальностями 241 "Готельно-ресторанна справа" та 242 "Туризм" за двома ОC "бакалавр" і "магістр" двох форм навчання - денної та заочної. У Національному університеті "Львівська політехніка" та Дрогобицькому державному педагогічному університеті ім. Івана Франка студенти зараховані на 2017/2018 н.р. тільки за спеціальністю 242 "Туризм". Найнижча вартість навчання за двома спеціальностями - у Львівському інституту економіки і туризму, а найвища - у Львівському національному університеті ім. Івана Франка. Загалом на навчання у заклади Львівщини зараховано 298 студентів на перший курс бакалаврату (3 них 252 на денну форму навчання, 72,6 \% ліцензованого обсягу) та 57 (з них 28 на денну форму навчання, 56 \% ліцензованого обсягу) на перший курс магістратури за спеціальністю "Готельно-ресторанна справа", а за спеціальністю "Туризм" 377 та 168 студентів відповідно (331 та 105 на денну форму навчання, $66,6 \%$ та 40,1 \% ліцензованого обсягу відповідно). Отже, можна зробити висновок, що освітній ринок Львівської обл. не є повністю заповнений і $є$ доволі конкурентним. Оскільки пропозиція перевищує попит, то цей ринок можна визначити як ринок споживача. Рейтингові позиції закладів вищої освіти Львівщини для двох спеціальностей 241 "Готельно-ресторанна справа" та 242 "Туризм" за кількістю поданих заяв абітурієнтами, кількістю зарахованих абітурієнтів на навчання, ліцензованого обсягу прийому та загального конкурсу подано у табл. 2, 3 . 
Табл. 1. Характеристика закладів вищої освіти Львівщини у сфері обслуговування

\begin{tabular}{|c|c|c|c|c|c|c|c|c|}
\hline Назва ВНЗ & $\begin{array}{l}\text { Спеціаль- } \\
\text { ність }\end{array}$ & $\mathrm{OC}$ & $\begin{array}{c}\text { Форма } \\
\text { навчан- } \\
\text { ня }\end{array}$ & $\begin{array}{c}\text { Вартість } \\
\text { навчан- } \\
\text { ня } \\
\end{array}$ & $\begin{array}{l}\text { кількість пода- } \\
\text { них заяв абіту- } \\
\text { рієнтами, од. }\end{array}$ & $\begin{array}{c}\text { кількість зара- } \\
\text { хованих абіту- } \\
\text { рієнті, осіб }\end{array}$ & $\begin{array}{c}\text { ліцензований } \\
\text { обсяг прийому, } \\
\text { місць }\end{array}$ & $\begin{array}{l}\text { загальний } \\
\text { конкурс, } \\
\text { осіб/місце }\end{array}$ \\
\hline $\begin{array}{c}\text { Дрогобицький ДПУ } \\
\text { ім. Івана Франка (ЛНУ) }\end{array}$ & 242 Туризм & Бакалавр & Заочна & 9000 & 29 & 6 & 30 & 0,97 \\
\hline \multirow{2}{*}{$\begin{array}{c}\text { Київський НУ культури } \\
\text { і мистецтв (Львівський } \\
\text { факультет) }\end{array}$} & 241 ГРС & Бакалавр & Денна & 9000 & 32 & 32 & 100 & 0,32 \\
\hline & 242 Туризм & Бакалавр & Денна & 9000 & 12 & 12 & 50 & 0,24 \\
\hline \multirow{6}{*}{$\begin{array}{c}\text { Львівський ДУ } \\
\text { фізичної культури } \\
\text { (ЛДУФК) }\end{array}$} & \multirow{2}{*}{241 ГРС } & \multirow{2}{*}{ Бакалавр } & Денна & 9000 & 67 & 67 & 82 & 0,82 \\
\hline & & & Заочна & 7000 & 5 & 5 & 15 & 0,33 \\
\hline & \multirow{4}{*}{242 Туризм } & \multirow{2}{*}{ Бакалавр } & Денна & 10500 & 59 & 59 & 140 & 0,42 \\
\hline & & & Заочна & 7500 & 8 & 8 & 40 & 0,2 \\
\hline & & \multirow{2}{*}{ Магістр } & Денна & 15000 & 32 & 32 & 75 & 0,43 \\
\hline & & & Заочна & 11000 & 10 & 10 & 25 & 0,4 \\
\hline \multirow{8}{*}{$\begin{array}{c}\text { Львівський } \\
\text { інститут економіки } \\
\text { і туризму (ЛІЕТ) }\end{array}$} & \multirow{4}{*}{241 ГРС } & \multirow{2}{*}{ Бакалавр } & Денна & 9000 & 288 & 20 & 25 & 11,52 \\
\hline & & & Заочна & 7000 & 23 & 2 & 15 & 1,53 \\
\hline & & \multirow{2}{*}{ Магістр } & Денна & 10000 & 17 & 15 & 20 & 0,85 \\
\hline & & & Заочна & 8000 & 7 & 6 & 20 & 0,35 \\
\hline & \multirow{4}{*}{242 Туризм } & \multirow{2}{*}{ Бакалавр } & Денна & 9000 & 250 & 8 & 25 & 10 \\
\hline & & & Заочна & 7000 & 22 & 3 & 15 & 1,47 \\
\hline & & \multirow{2}{*}{ Магістр } & Денна & 10000 & 12 & 10 & 25 & 0,48 \\
\hline & & & Заочна & 8000 & 8 & 7 & 25 & 0,32 \\
\hline \multirow{6}{*}{$\begin{array}{c}\text { Львівський НУ } \\
\text { ім. Івана Франка (ЛНУ) }\end{array}$} & \multirow{2}{*}{241 ГРС } & \multirow{2}{*}{ Бакалавр } & Денна & 13044 & 964 & 72 & 75 & 12,85 \\
\hline & & & Заочна & 9131 & 143 & 15 & 25 & 5,72 \\
\hline & \multirow{4}{*}{242 Туризм } & \multirow{2}{*}{ Бакалавр } & Денна & 13044 & 2099 & 95 & 97 & 21,64 \\
\hline & & & Заочна & 9131 & 187 & 10 & 100 & 1,87 \\
\hline & & \multirow{2}{*}{ Магістр } & Денна & 16509 & 54 & 28 & 100 & 0,54 \\
\hline & & & Заочна & 11556 & 58 & 34 & 50 & 1,16 \\
\hline \multirow{6}{*}{$\begin{array}{c}\text { Львівський } \\
\text { торговельно-економічний } \\
\text { університет }\end{array}$} & \multirow{4}{*}{241 ГРС } & \multirow{2}{*}{ Бакалавр } & Денна & 12500 & 66 & 61 & 65 & 1,02 \\
\hline & & & Заочна & 9800 & 24 & 24 & 65 & 0,37 \\
\hline & & \multirow{2}{*}{ Магістр } & Денна & 14700 & 13 & 13 & 30 & 0,43 \\
\hline & & & Заочна & 12200 & 23 & 23 & 40 & 0,58 \\
\hline & \multirow{2}{*}{242 Туризм } & \multirow{2}{*}{ Бакалавр } & Денна & 12500 & 44 & 43 & 60 & 0,73 \\
\hline & & & Заочна & 9800 & 8 & 8 & 40 & 0,2 \\
\hline \multirow{4}{*}{$\begin{array}{c}\text { НУ "Львівська } \\
\text { політехніка" } \\
\text { (НУ "ЛП") }\end{array}$} & \multirow{4}{*}{242 Туризм } & & Денна & 10500 & 1305 & 114 & 125 & 10,44 \\
\hline & & | Бакалавр & Заочна & 7500 & 98 & 11 & 20 & 4,9 \\
\hline & & Mad & Денна & 12000 & 59 & 35 & 60 & 0,98 \\
\hline & & Магістр & Заочна & 9000 & 26 & 12 & 40 & 0,65 \\
\hline
\end{tabular}

Табл. 2. Рейтингові позиції закладів вищої освіти Львівщини за спеціальністю 241 "Готельно-ресторанна справа"

\begin{tabular}{|c|c|c|c|c|c|c|c|c|c|c|c|c|c|c|}
\hline \multirow{3}{*}{ Назва ВНЗ } & \multicolumn{8}{|c|}{ Частка вищого навчального закладу } & \multirow{2}{*}{\multicolumn{2}{|c|}{$\begin{array}{c}\text { Рейтингове } \\
\text { число }\end{array}$}} & \multirow{2}{*}{\multicolumn{2}{|c|}{$\begin{array}{c}\text { Рейтингова } \\
\text { позиція }\end{array}$}} & \multirow{3}{*}{$\begin{array}{l}\text { Консолідо- } \\
\text { ване } \\
\text { рейтингове } \\
\text { число }\end{array}$} & \multirow{3}{*}{$\begin{array}{l}\text { Рейтин- } \\
\text { гова } \\
\text { позиція }\end{array}$} \\
\hline & \multicolumn{2}{|c|}{$\begin{array}{l}\text { за кількістю } \\
\text { поданих заяв }\end{array}$} & \multicolumn{2}{|c|}{$\begin{array}{l}\text { за кількістю } \\
\text { зарахованих } \\
\text { абітурієнтів } \\
\end{array}$} & \multicolumn{2}{|c|}{$\begin{array}{c}\text { за ліцензова- } \\
\text { ним обсягом } \\
\text { прийому }\end{array}$} & \multicolumn{2}{|c|}{$\begin{array}{c}\text { за загальним } \\
\text { конкурсом }\end{array}$} & & & & & & \\
\hline & $\begin{array}{l}\text { бака- } \\
\text { лавр }\end{array}$ & $\begin{array}{c}\text { ма- } \\
\text { гістр }\end{array}$ & $\begin{array}{l}\text { бака- } \\
\text { лавр }\end{array}$ & $\begin{array}{c}\text { ма- } \\
\text { гістр }\end{array}$ & $\begin{array}{l}\text { бака- } \\
\text { лавр }\end{array}$ & $\begin{array}{c}\text { ма- } \\
\text { гістр }\end{array}$ & $\begin{array}{l}\text { бака- } \\
\text { лавр }\end{array}$ & $\begin{array}{c}\text { ма- } \\
\text { гістр }\end{array}$ & $\begin{array}{l}\text { бака- } \\
\text { лавр }\end{array}$ & $\begin{array}{c}\text { ма- } \\
\text { гістр }\end{array}$ & $\begin{array}{l}\text { бака- } \\
\text { лавр }\end{array}$ & $\begin{array}{c}\text { ма- } \\
\text { гістр }\end{array}$ & & \\
\hline $\begin{array}{c}\text { Київський } \\
\text { НУКіМ } \\
\text { (Львівський } \\
\text { факультет) } \\
\end{array}$ & 0,02 & 0,00 & 0,11 & 0,00 & 0,21 & 0,00 & 0,02 & 0,00 & 0,36 & 0,00 & 5 & - & 0,36 & 5 \\
\hline $\begin{array}{c}\text { Львівський } \\
\text { ДУФК }\end{array}$ & 0,04 & 0,00 & 0,24 & 0,00 & 0,21 & 0,00 & 0,04 & 0,00 & 0,53 & 0,00 & 4 & - & 0,53 & 4 \\
\hline $\begin{array}{c}\text { Львівський } \\
\text { IЕiT } \\
\end{array}$ & 0,19 & 0,40 & 0,07 & 0,37 & 0,09 & 0,36 & 0,38 & 0,54 & 0,73 & 1,67 & 2 & 2 & 2,40 & 2 \\
\hline $\begin{array}{c}\text { Львівський } \\
\text { НУ ім. } \\
\text { Франка } \\
\end{array}$ & 0,69 & 0,00 & 0,29 & 0,00 & 0,21 & 0,00 & 0,54 & 0,00 & 1,73 & 0,00 & 1 & - & 1,73 & 3 \\
\hline $\begin{array}{c}\text { Львівський } \\
\text { ТЕУ } \\
\end{array}$ & 0,06 & 0,60 & 0,29 & 0,63 & 0,28 & 0,64 & 0,03 & 0,46 & 0,65 & 2,33 & 3 & 1 & 2,98 & 1 \\
\hline
\end{tabular}

Джерело: авторська розробка.

Визначення рейтингової позиції проведено за такою методикою:

1) значення показників формувались як сума значень показників денної та заочної форм навчання;

2) розрахунок частки кожного ЗВО за кожним показником;

3) визначення рейтингового числа як алгебраїчної суми часток ЗВО за усіма показниками; значення консолідованого рейтингового числа визначається як сума рейтингових чисел для двох освітніх ступенів "бакалавр" і "магістр";

4) ранжування ЗВО за значенням (консолідованого) рейтингового числа: більшому значенню (консолідовано- го) рейтингового числа відповідає вища рейтингова позиція.

Як показують результати рейтингування закладів вищої освіти Львівщини за спроможністю залучити якомога більшу кількість абітурієнтів, за результатами вступної кампанії 2017 р. за спеціальністю "Готельноресторанна справа" найвищі рейтингові позиції належать Львівському торговельно-економічному університету (1 місце), Львівському інституту економіки і туризму (2 місце) та Львівському національному університету ім. Франка (3 місце). У рейтингу $3 \mathrm{BO}$ за спеціальністю "Туризм" лідерами є Львівський національний 
університет ім. Франка (1 місце), Національний університет "Львівська політехніка" (2 місце) та Львівський державний університет фізичної культури (3 місце). Ви- соке значення консолідованого рейтингового числа характерне і для Львівського інституту економіки і туризму (4 місце).

Табл. 3. Рейтингові позиції закладів вищої освіти Львівщини за спеціальністю 242 "Туризм"

\begin{tabular}{|c|c|c|c|c|c|c|c|c|c|c|c|c|c|c|}
\hline \multirow{3}{*}{ Назва ВНЗ } & \multicolumn{8}{|c|}{ Частка вищого навчального закладу } & \multirow{2}{*}{\multicolumn{2}{|c|}{$\begin{array}{l}\text { Рейтингове } \\
\text { число }\end{array}$}} & \multirow{2}{*}{\multicolumn{2}{|c|}{$\begin{array}{l}\text { Рейтингова } \\
\text { позиція }\end{array}$}} & \multirow{3}{*}{$\begin{array}{c}\text { Консо- } \\
\text { лідова- } \\
\text { не } \\
\text { рейтин- } \\
\text { гове } \\
\text { число } \\
\end{array}$} & \multirow{3}{*}{$\begin{array}{c}\text { Рейтин } \\
\text { гова } \\
\text { пози- } \\
\text { ція }\end{array}$} \\
\hline & \multicolumn{2}{|c|}{$\begin{array}{r}\text { за кількістю } \\
\text { поданих заяв }\end{array}$} & \multicolumn{2}{|c|}{$\begin{array}{l}\text { за кількістю } \\
\text { зарахованих } \\
\text { абітурієнтів }\end{array}$} & \multicolumn{2}{|c|}{$\begin{array}{c}\text { за ліцензова- } \\
\text { ним обсягом } \\
\text { прийому }\end{array}$} & \multicolumn{2}{|c|}{$\begin{array}{c}\text { за загальним } \\
\text { конкурсом }\end{array}$} & & & & & & \\
\hline & $\begin{array}{l}\text { бака- } \\
\text { лавр }\end{array}$ & $\begin{array}{c}\text { ма- } \\
\text { гістр }\end{array}$ & $\begin{array}{l}\text { бака- } \\
\text { лавр }\end{array}$ & $\begin{array}{c}\text { ма- } \\
\text { гістр }\end{array}$ & $\begin{array}{l}\text { бака- } \\
\text { лавр }\end{array}$ & $\begin{array}{l}\text { ма- } \\
\text { гістр }\end{array}$ & $\begin{array}{l}\text { бака- } \\
\text { лавр }\end{array}$ & $\begin{array}{c}\text { ма- } \\
\text { гістр }\end{array}$ & $\begin{array}{l}\text { бака- } \\
\text { лавр }\end{array}$ & $\begin{array}{l}\text { ма- } \\
\text { гістр }\end{array}$ & $\begin{array}{l}\text { бака- } \\
\text { лавр }\end{array}$ & $\begin{array}{c}\text { ма- } \\
\text { гістр }\end{array}$ & & \\
\hline $\begin{array}{c}\text { Дрогобицький } \\
\text { ДПУ ім. Івана } \\
\text { Франка } \\
\end{array}$ & 0,01 & 0,00 & 0,02 & 0,00 & 0,04 & 0,00 & 0,03 & 0,00 & 0,10 & 0,00 & 7 & - & 0,10 & 7 \\
\hline $\begin{array}{c}\text { Київський НУ- } \\
\text { КіМ (Львівський } \\
\text { факультет) } \\
\end{array}$ & 0,00 & 0,00 & 0,03 & 0,00 & 0,07 & 0,00 & 0,01 & 0,00 & 0,11 & 0,00 & 6 & - & 0,11 & 6 \\
\hline $\begin{array}{c}\text { Львівський } \\
\text { ДУФК }\end{array}$ & 0,02 & 0,16 & 0,18 & 0,25 & 0,24 & 0,25 & 0,01 & 0,17 & 0,45 & 0,84 & 3 & 3 & 1,28 & 3 \\
\hline Львівський IEiT & 0,07 & 0,08 & 0,03 & 0,10 & 0,05 & 0,13 & 0,23 & 0,17 & 0,37 & 0,47 & 4 & 4 & 0,84 & 4 \\
\hline $\begin{array}{l}\text { Львівський НУ } \\
\text { ім. Франка }\end{array}$ & 0,55 & 0,43 & 0,28 & 0,37 & 0,27 & 0,38 & 0,38 & 0,31 & 1,48 & 1,49 & 1 & 1 & 2,97 & 1 \\
\hline ЛЬВівський ТЕУ & 0,01 & 0,00 & 0,14 & 0,00 & 0,13 & 0,00 & 0,02 & 0,00 & 0,30 & 0,00 & 5 & - & 0,30 & 5 \\
\hline $\begin{array}{c}\text { НУ "Львівська } \\
\text { політехніка" }\end{array}$ & 0,34 & 0,33 & 0,33 & 0,28 & 0,20 & 0,25 & 0,32 & 0,35 & 1,19 & 1,21 & 2 & 2 & 2,40 & 2 \\
\hline
\end{tabular}

Джерело: авторська розробка.

Вивчивши наукові праці вчених, проаналізувавши діяльність закладів вищої освіти України, зокрема, і Львівської обл., а також з власного досвіду можемо виокремити такі інноваційні методи та форми організації освітнього процесу, які дають змогу підвищити конкурентоспроможність закладів вищої освіти, покращити якість освітніх послуг та підготовити кваліфікованих спеціалістів для роботи у сфері туризму та готельноресторанного бізнесу:

- вивчення іноземних мов (англійської, німецької), що повинно тривати впродовж усього навчального процесу;

- упровадження новітніх інформаційно-комунікаційних технологій у навчальній діяльності;

- використання технологій проблемного, імітаційного, комп'ютерного, інтерактивного навчання у сфері туризму та готельно-ресторанного бізнесу;

- застосування у навчальному процесі кейс-технологій, зокрема: методу ситуаційного аналізу, інциденту, проектування, дискусії тощо, що дасть змогу створити умови для формування нових та ефективніших навичок професійної діяльності у сфері туризму та готельно-ресторанної справи (Маkovetska, 2014);

- організація та проведення веб-квестів, тренінгів, які сформують комунікативні навички у студентів під час спілкування з туристами;

- впровадження ігрових методів і технологій навчання, а саме: ділових ігор, відеопрактикумів, методу "Мозкової атаки", які дають змогу розвивати у студентів пізнавальну діяльність, вирішувати навчальні завдання з урахуванням колективних та індивідуальних думок, удосконалювати систему професійної підготовки, що дає змогу відпрацювати професійні навички студентів, окрім цього, оцінити: вміння прогнозувати ситуацію та приймати рішення; рівень володіння організаційними та комунікативними навичками; професійно важливі якості майбутнього фахівця 3 туризму (Vinduk, 2015);

- застосування проектної технології для навчання, ефективність якої пояснюють можливістю: по-перше, організовувати дослідно-пошукову роботу; по-друге, створювати умови для контекстного навчання. Технологія проектів дає змогу застосовувати різні дидактичні підходи: навчання в роботі, незалежні знання, спільне навчання (командне навчання), дискусії, навчання на власному досвіді та на досвіді інших, урешті все це дає задоволення учням, оскільки вони бачать результати своєї праці (Martyniuk, 2014);
- забезпечення здійснення дистанційної освіти завдяки розробці онлайн курсів на основі інформаційно-комунікаційних технологій;

- реалізація практико-орієнтованого підходу у процесі професійної підготовки майбутніх фахівців з готельної і ресторанної справи. Практико-орієнтований підхід до навчання передбачає таке навчання, метою якого $є$ формування у студентів професійних навичок практичної роботи, затребуваних роботодавцями, а також формування розуміння того, де, як і для чого отримані навички та компетенції застосовувати на практиці. Навчання на основі практико-орієнтованого підходу повинно орієнтуватися на конкретну практику, а не на підручники, має здійснюватися у тісній співпраці навчальних закладів і виробничих організацій. Студенти повинні освоювати якусь певну діяльність не за підручниками, а безпосередньо залучаючись у iii найпростіші форми. Змістом такого навчання стає зміст діяльності - iї форми організації, способи роботи, робочі операції тощо (Pitsul, 2016).

Провідним закладом вищої освіти, який готує фахівців для ведення підприємництва (бізнесу) у сфері туристичного бізнесу, є Львівський інститут економіки і туризму (ЛІЕТ), який здійснює підготовку бакалаврів та магістрів за 7 спеціальностями, серед яких 4 економічні: менеджмент; підприємництво, торгівля та біржова діяльність; облік та оподаткування; міжнародні економічні відносини. Три інші спеціальності - туризм; готельно-ресторанна справа; технології харчування належать до сфери послуг та гостинності. Професійна підготовка майбутніх фахівців з туристичної діяльності грунтується на відповідності надання знань, навичок та компетенцій майбутній професійній діяльності. Сьогоднішній підхід в ЛІЕТ- це реалізація гасла "Навчання не тільки заради диплому, а заради належного працевлаштування".

Основним завданням викладачів ЛIЕТ $\epsilon$ формування конкурентоспроможних фахівців, які мають підприємницькі навички, здатні працювати в команді, ініціативних, відповідальних, готових до ефективної діяльності за фахом на конкурентному ринку праці. Підготовка фахівця організована так, щоб в іiі процесі знання, вміння та навички трансформувалися в певну компетентність, необхідну в професійній сфері. Професійна компетентність випускників інституту $є$ основою ефективної самореалізації на ринку праці, це результат підготов- 
ки фахівця для виконання діяльності в певних професійних та соціально особистісних предметних галузях (компетенціях), який визначається необхідним обсягом і рівнем знань та досвіду у певному виді діяльності.

Під час навчання в ЛІЕТ майбутні фахівці туристичної діяльності оволодівають практичними навичками проектування та складання турів і екскурсій, організації різних видів туризму, комунікативними навичками, вміють вирішувати конфліктні та інші професійні ситуації, створювати нові туристичні продукти та послуги, власний бізнес; створювати різні види юридичних осіб для підприємницької діяльності; обирати найефективнішу форму господарювання як в Україні, так і за кордоном; розробляти бізнес-плани; шукати джерела фінансування інвестиційних проектів. Студенти вміють шукати та аналізувати інформацію про пріоритетні напрями в туризмі, описувати та презентувати власні ідеї, представляти інформацію потенційним інвесторам, проводити переговори 3 інвестором. Окрім загальних для спеціальності знань і умінь, випускники інституту одержують компетенції організації власного бізнесу, вміння розвивати свій бізнес, щоб посісти позиції лідера в своїй ніші, здатності створення малих підприємств, ефективного управління ними в умовах нестабільної економіки, отримують грунтовну правову підготовку у сфері організації і здійснення підприємницької діяльності, мають змогу працювати на підприємствах різних форм власності.

Інститут готує професіоналів, які знають як працюють сучасні підприємства сфери послуг, які інструменти сервіс-менеджменту є ефективними, як їх правильно застосовувати. Перевагами випускників $є$ високий рівень зарплати, стабільний попит на ринку праці, широкий спектр можливих місць працевлаштування. Конкурентоспроможним можна вважати такий 3ВО, де проводять постійні наукові дослідження, а в навчальних планах присутні такі форми навчання, як тренінги, проектні розробки, науково-дослідна робота, ефективність якої залежить від пізнавальної та творчої активності студентів, підвищення якої досягається в ЛІЕТ за допомогою інноваційних інтегрованих магістерських програм науково-дослідної та тренінгової роботи, метою яких є підготовка висококваліфікованих конкурентоспроможних на сучасному ринку праці фахівців для підприємств туристичної індустрії, здатних успішно започаткувати власну справу, професійно вирішувати практичні проблеми управління підприємствами туристичної індустрії і забезпечувати їх сталий розвиток, реалізувати підприємницькі здібності, ефективно управляти бізнес-процесами компаній та забезпечувати зростання ix ринкової вартості у динамічному конкурентному середовищі; формування у студентів компетенцій для виконання функціональних обов'язків у туристичному та готельно-ресторанному бізнесі, виконанні управлінських функцій, наукової роботи, інноваційної діяльності, здатності організувати бізнес, відкритті нового бізнесу, створенні стартапів.

Організацію освітнього процесу в ЛІЕТ з магістрами здійснюють за двома складниками: проведення інтегрованих та інтерактивних занять (рольових ігор, ділових ситуацій, наукових семінарів, практичних конференцій); організація науково-дослідної і тренінгової роботи кожним студентом під керівництвом викладача-дослідника. Студенти розробляють бізнес-ідеї, концепції, досліджують ринкову доцільність своїх ідей, визначають необхідні ресурси для створення життєздатного бізне- су, створення стартапів доступних для їх реалізації. Науково-дослідна робота студентів спрямована на те, щоб вони не тільки володіли знаннями, але й вміли застосовувати їх у процесі власної самостійної наукової, дослідницької і творчої діяльності. Освітній процес в інституті постійно оновлюється завдяки впровадженню інтерактивних методів навчання, інноваційних технологій, що передбачають використання сучасного комп'ютерного та мультимедійного обладнання.

Під час викладання дисциплін викладачі застосовують новітні інформаційно-комунікаційні технології, проблемні та ігрові методи, вирішення яких потребує не тільки теоретичних знань, але й практичних вмінь тощо. Для підвищення мотивації студентів до навчання викладачі ЛІЕТ використовують активні форми навчання: ділові ігри, рольові ігри, кейс-методи, тренінги, метод "мозкового штурму", "дерево рішень", проектні форми роботи, проектування та моделювання нестандартних виробничих ситуацій і пошук новітніх способів їхнього вирішення, дебати, складання кросвордів, технології опрацювання дискусійних питань, розв'язання кейсів і ситуаційних завдань, проведення бізнес-тренінгів. Застосування інтерактивних методів навчання підвищує інтерес студентів до занять, сприяє зростанню рівня управлінських знань, вмінь і навичок, а також підвищує їх мотивацію до навчання та готовність до роботи у туристичному, готельно-ресторанному бізнесі. Підвищення ефективності інтеграції навчальної та наукової роботи, залучення студентів до науково-дослідної та тренінгової діяльності підвищує якість підготовки фахівців і робить їх конкурентоспроможними на ринку праці.

Висока конкурентоспроможність випускників ЛІЕТ визначається такими компетенціями: володіння професійними практичними навичками, отриманими внаслідок реалізації інноваційних навчальних технологій, зокрема, кейс-методів, проектних завдань, тренінгових технологій; готовність до управлінської, організаційної, фінансової, маркетингової, аналітичної, проектно-дослідницької діяльності; володіння професійними та базовими компетенціями, пов'язаними із здатністю до системного мислення та прийняття управлінських рішень у фінансовій сфері; володіння англійською мовою та сучасними комп'ютерними технологіями оброблення фінансової інформації; володіння навичками проведення наукових досліджень 3 використанням сучасного дослідницького інструментарію.

Висновки. Соціально-економічний розвиток нашої держави, процеси глобалізації, інтеграції та інформатизації суспільства визначили принципово нові вимоги до професійної підготовки фахівців, зокрема, у сфері туризму. Це зумовлено тим, що туристській галузі потрібні спеціалісти, які могли б працювати самостійно і творчо, генеруючи компетентні нововведення, свіжі ідеї та пропозиції, демонструючи при цьому готовність успішно реалізовувати їх в умовах конкуренції. Успішність реалізації практичних туристських завдань залежить насамперед від підготовки фахівців (Saffransky, 2015). Основними умовами підвищення конкурентоспроможності закладів вищої освіти у сфері професійної туристичної освіти $є$ активне використання інноваційних методів та форм для розвитку і удосконалення якості й ефективності навчального процесу та підготовки фахівців у сфері туризму та готельно-ресторанної справи, орієнтуючись на досвід найкращих закладів вищої освіти не тільки України, а й досягнень світової науки, техніки та передового досвіду. 


\section{Перелік використаних джерел}

Babeshko, M. Sc. (2016). Peculiarities of the preparation of specialists in hotel and restaurant business for professional activity at a higher educational institution. Pedagogy of the formation of a creative person in higher and secondary schools, 46, 277-282. [In Ukrainian].

Butenko, O. P., \& Strelchenko, D. O. (2016). The state of the restaurant economy of Ukraine and prospects of its development. Bulletin of economy of transport and industry, 56, 18-24. [In Ukrainian].

Grytsyuk, M. Yu., \& Hrytsiuk, Yu. I. (2013). Metody kompleksnoho otsiniuvannia variantiv stratehichnoho rozvytku turystychnoi haluzi. Bulletin of the National University "Lviv Polytechnic". Series of Computer Sciences and Information Technologies, 672, 110-119. Lviv: Vyd-vo NU "Lvivska politekhnika". [In Ukrainian].

Makovetska, N. V. (2014). Use of innovative technologies in the educational process of training future specialists in the field of tourism. Pedagogy of forming a creative person in higher and secondary schools, 36, 303-308. [In Ukrainian].

Martyniuk, I. A. (2014). Technologies of Project Training in Preparing an Agent for Tourism Organization. Scientific Bulletin of the
National University of Life and Environmental Sciences of Ukraine, 199(2), 196-204. [In Ukrainian].

Pitsul, K. S. (2016). Model of formation of preparedness for professional activity of future specialists in hotel and restaurant business as a result of professional training. Herald of Dnipropetrovsk University named after. A. Nobel. Series: Pedagogy and Psychology, 1. [In Ukrainian].

Saffransky, V. V. (2015). Basic requirements for specialists in the sphere of tourism and features of tourist education in higher educational institutions. Galician Economic Journal, 2(49). [In Ukrainian].

Savitska, O. P., \& Savitska, N. V. (2013). Theoretical and methodical aspects of assessing the competitiveness of subjects of the tourism industry. Bulletin of the National University "Lviv Polytechnic". Management and Entrepreneurship in Ukraine: Stages of Development and Developmental, 776, 154-163. [In Ukrainian].

Vinduk, A. V. (2015). The use of game techniques in the professional training of bachelors in tourism. Scientific journal NPU Drahomanov NPO. Series 15, 11, 29-31. [In Ukrainian].

Г. Я. Дутка

Львовский институт экономики и туризма, г. Львов, Украина

\title{
КОНКУРЕНТОСПОСОБНОСТЬ ВЫСШИХ УЧЕБНЫХ ЗАВЕДЕНИЙ ЛЬВОВСКОЙ ОБЛАСТИ В ПОДГОТОВКЕ БУДУЩИХ СПЕЦИАЛИСТОВ ТУРИСТИЧЕСКОГО И ГОСТИНИЧНО-РЕСТОРАННОГО БИЗНЕСА
}

\begin{abstract}
Исследованы тенденции и перспективы развития туристического и гостинично-ресторанного бизнеса Украины. Сравнительный анализ научных работ отечественных и зарубежных ученых показал, что одним из условий эффективного развития туристической сферы и гостинично-ресторанного бизнеса является наличие высококвалифицированных кадров, способных принимать эффективные управленческие решения, обеспечивая конкурентоспособность как отдельных предприятий, так и отрасли в целом. Усиление конкуренции в сфере образовательной деятельности требует от высших учебных заведений постоянно совершенствовать свою деятельность по всем ее направлениям, улучшать качество преподавания, мобилизует заведение в рыночных условиях. Проанализировано современное состояние высших учебных заведений Украины в сфере обслуживания; определена рейтинговая позиция высших учебных заведений Львовщины. Исследованы концепции и механизмы повышения конкурентоспособности высших учебных заведений в современных условиях. Выявлены конкурентные позиции и уровень использования образовательного потенциала вузами Львовской области подготовки специалистов сферы обслуживания, в частности, по специальностям 241 "Гостинично-ресторанное дело" и 242 "Туризм" по данным вступительной кампании 2017 г. Предложены инновационные методы и формы, которые целесообразно внедрять в образовательной деятельности высших учебных заведений для повышения их конкурентоспособности, улучшения качества услуг и подготовки квалифицированных специалистов.
\end{abstract}

Ключевые слова: учреждение высшего образования; сфера услуг; туризм; гостинично-ресторанное дело; стоимость обучения; лицензированный объем приема; общий конкурс; инновационные методы обучения.

G. Ya. Dutka

Lviv Institute of Economics and Tourism, Lviv, Ukraine

\section{COMPETITIVENESS OF HIGHER EDUCATION INSTITUTIONS OF LVIV REGION IN THE PREPARATION OF FUTURE FACTORS OF THE TOURIST AND HOTEL RESTAURANT BUSINESS}

The article investigates tendencies and prospects of development of tourist and hotel-restaurant business of Ukraine. A comparative analysis of the scientific works of domestic and foreign scientists showed that one of the conditions for the effective development of the tourism industry and hotel and restaurant business is the presence of highly skilled personnel capable of taking effective managerial decisions, ensuring the competitiveness of both individual enterprises and the industry as a whole. Increasing competition in the field of educational activity requires institutions of higher education to continuously improve their activities in all its areas, improve the quality of teaching that mobilizes the institution in market conditions. Competitive advantages are those educational institutions and specialties that provide higher quality of specialists training, when the received education guarantees future specialists the realization of their own abilities, the acquisition of modern knowledge, skills and abilities, a sufficient level of remuneration, and competitiveness as specialists in the labour market. The author analyses the current state of higher education institutions in Ukraine in the field of services. The rating position of institutions of higher education of Lviv region is determined. Concepts and mechanisms of increasing the competitiveness of institutions of higher education in modern conditions are investigated. Competitive positions and the level of use of educational potential by higher education institutions of the Lviv region were determined by the training of specialists in the sphere of services, in particular, in specialities 241 "Hotel and Restaurant Business" and 242 "Tourism" according to the 2017 admission campaign. The innovative methods and forms, which are expedient to introduce in higher educational institutions educational activity, are offered in order to increase their competitiveness, improve the quality of educational services and prepare qualified specialists. The main conditions for increasing the competitiveness of higher education institutions are the active use of innovative methods and forms for the development and improvement of the quality and efficiency of the educational process and training of specialists in the field of tourism and hotel and restaurant business, focusing on the experience of the best institutions of higher education not only in Ukraine, but also the achievements of science and best practices of the world.

Keywords: institution of higher education; sphere of services; tourism; hotel and restaurant business; tuition fees; licensed volume of admission; general competition; innovative teaching methods. 